\title{
Phonotactic Adjustments in Yoruba Adaptation of English Syllable Structures
}

\author{
Toyin Bamisaye, George Adekunle 0jo \\ Department of English and Literary Studies, Ekiti State University, Ado-Ekiti, Nigeria \\ Email: etobamisaye@yahoo.com, georgeade4life@yahoo.com
}

Received 6 July 2015; accepted 24 August 2015; published 27 August 2015

Copyright (C) 2015 by authors and Scientific Research Publishing Inc.

This work is licensed under the Creative Commons Attribution International License (CC BY).

http://creativecommons.org/licenses/by/4.0/

(c) (i) Open Access

\begin{abstract}
This paper examines the phonotactic processes in Yoruba adaptation of English syllable structures. It investigates the nativization of English consonant structure in the word-initial and word-final positions by Yoruba-English bilinguals. From the contact and influence of the English language and Yoruba language in an ESL environment, the fundamental thrust of linguistics would be to explicate the influence that one language would have on another. In this case, the focus is on the effects the English has on Yoruba. When these effects are viewed, it is discovered that structural rules are affected. Our findings reveal that vowel epenthesis is not constantly the repair device. Analysis of data shows that consonants are either preserved or deleted which justifies the earlier position of scholars of foreign syllable modifications.
\end{abstract}

\section{Keywords}

Phonotactics, Adaptation, Phoneme, Epenthesis, Nativization

\section{Introduction}

English and Yoruba languages came in contact when the missionaries came to Yoruba land in search of business succour and also to propagate the gospel of Jesus Christ. In the early $19^{\text {th }}$ century, those missionaries had infiltrated the lifestyles of the Yoruba people. This encroachment affected their social, political, economic and religious activities. English, being the major medium of expression and administration during this period, became an essential phenomenon in the Yoruba speech community.

Most Yoruba speakers of English embraced foreign items and introduced them into their language (since most of the foreign words have no ready substitutes in their native language) while speaking in their mother tongue. These foreign words were fully adapted into the linguistic system of Yoruba. However, the foreign words are more pronounced in certain activities, most of which are foreign to the Yoruba, such as occupations (dírébà 
“driver”, mékáníìì “mechanic”, tísà “teacher”, télò “tailor”); religion (sóòsì “church”, bíbélì “bible”, pásítò “pastor”, ìmámù “imam”); law (kóòtù “court”, lòyà "lawyer”, béèlì "bail”, ódà “order”); technology (fóònù "phone”, fídíò “video”, rédíò "radio”, fáànù “fan”, mótò “motor”) etc.

However, Yoruba being one of the African languages is a tonal language and this tonal feature has strong implication on the rendition of English words by Yoruba-English bilinguals. This tonal melody is usually superimposed on English utterances. In other words, these Yoruba tones are co-articulated with the English segments.

The syllable structures of the two languages are different from each other, but in order to fit into the template of the Yoruba syllable structure, there are modifications of the English syllable structure through either vowel epenthesis or consonant deletion.

These foreign words which enjoy a prime place among Yoruba people have become part and parcel of the linguistic system of Yoruba. Therefore, they are acquired at the early stage of the Yoruba children as Yoruba structures, hence, impairing them the tendency of speaking standard Yoruba language and also preventing the proper learning and speaking of the English language.

When a syllable structure that is permitted in English is adapted into Yoruba, it will undergo some phonotactic modifications to make it conform to the syllable templates of the recipient language. For instance, if a word is borrowed from a language that allows a sequence of consonants (consonant cluster) into Yoruba-a language that does not permit consonant cluster-it is either an epenthetic vowel is employed to break up the consonant cluster or one of the consonants in the sequence is deleted. This paper is aimed at investigating phonotactic modifications of foreign (English) lexical items.

\section{Literature Review}

In the literature, it has been reported that besides vowel epenthesis, consonant preservation and consonant deletion are also major phonotactic processes in the adaptation of borrowed words. Syllable structures that are forbidden in the recipient structure can be modified through either preservation or deletion of segments. These two common strategies in the adaptation of foreign lexical items have been reported in various studies on foreign word processes. Divergent opinions have been submitted by different studies on loanword phonology. A group of scholars, such as (Silverman, 1992; Paradis, 1996; Dupoux \& Perperkamp, 2002; Uffmann, 2006; Kang, 2003, 2007; Kenstowicz, 2007) argue that vowel epenthesis is the only and commonly used strategy in resolving forbidden syllable structure which opposes consonant deletion.

In his phonotactic study of foreign syllable structures, Yip (1993) opines that the probability of consonant deletion is connected with the perceptual salience of the target phonemes. He observes that the class and the environment of occurrence of a phoneme in a syllable structure determine the choice between vowel epenthesis and consonant deletion in the adaptation of foreign words. The implication of these patterns in loanword processing is that a salient segment will be retained while a segment that is not salient will be deleted.

While studying loanword processes, Brasington (1997) discovers that in the adaptation of English words, segment position in the syllable and cluster structure must first be considered before the choice between vowel insertion and consonant deletion is made. He concludes that vowel epenthesis is highly favoured in the breaking of the onset clusters while consonant deletion is frequent in resolving clusters at the word-final positions.

Miao (2005) reports that in loanword processes, the changeability in segmental mapping is constrained by phonological factors so that the resultant loan form will retain sufficient similarity to the source form. He maintains further that contextual factors, such as stress may influence repair strategy. He says that besides vowel epenthesis, consonant preservation and consonant deletion vary across languages.

Kang (2007) posits that in loanword processes, the probability of the choice between vowel epenthesis and consonant deletion in segmental mappings is greatly determined by the process that results in maximal perceptual resemblance between the foreign input and the recipient output. This position is based on a survey of adaptation of word-final plosives from English loans. She concludes that vowel epenthesis is likely to be highly ranked when a high vowel is preceded by a final consonant.

This present study investigates the patterns of the adaptation of English borrowed words by Yoruba-English bilinguals from the perspective of perceptual resemblance. Following the arguments of the scholars mentioned above, this study supports the proposal that borrowed word phonology maximally produces an adapted form that is perceived by the recipient language speaker as most similar to the foreign source pronunciation using Yoruba-English bilinguals as a case study. 


\section{Methodology}

The data for this study were gathered from foreign lexical items borrowed into the structure of Yoruba language. The data were drawn from Yoruba-English bilinguals who freely mix English codes with their native language. These speakers include the artisans, businessmen and women, traders, hawkers, contractors, broadcasters, etc. The data were collected from various sources, such as different Yoruba news broadcasts and varieties of programmes. These programmes include professional talk-shows of different fields, such as science and technology, politics, law, medicine, current affairs etc. Data were also sourced from unscheduled oral dialogues with the selected members of the speech community under study. Different dialogues with these selected groups were recorded on a Digital Tape Recorder (DTR) and the tapes were later played back for analyses. The dialogues that involved Yoruba-English bilinguals who employed English loanwords in their day-to-day linguistic activities were done discretely so as to ensure their objective participations.

Most of these foreign lexical items do not share the same syllable structure with the syllable template of Yoruba. The syllable structure of Yoruba is $\mathrm{C}^{0-1} \mathrm{~V}$ which does not permit a sequence of consonants (consonant cluster) while the syllable structure of English is $\mathrm{C}^{0-3} \mathrm{VC}^{0-4}$ which allows consonant cluster.

Two theoretical models were adopted for the analysis of data in this study. This is because a single model cannot sufficiently handle all the aspects of the data analysis. The tonal features which characterize English words that are borrowed into Yoruba motivated the choice of Autosegmental Phonology. The level tonemes in Yoruba are High [H], Mid [M] and Low [L]. The borrowed English words are adapted and subjected to these tonal patterns. The domain of tone is the syllable. Every syllable contains a Tone-Bearing Unit (TBU). Every TBU (vowel or syllabic nasal in Yoruba) is associated with a tone.

The choice of the second model, Optimality Theory (OT), was borne out of the variations that exist between the syllable structures of the two languages. This theory plays a significant role in resolving the syllable structure of words borrowed from English into Yoruba.

\section{Data Analysis and Discussions}

This section analyzes and discusses the data gathered for the purpose of this study. The data have been classified into two categories which include cluster at the onset and cluster at the coda. Here, we are going to examine one to three consonants word-initially and one to four consonants word-finally.

\subsection{Modification of CC Clusters at the Onset}

There are three notable processes that have been discovered by scholars (e.g. Miao, 2005) to simplify CC cluster at the onset. First, a vowel could be inserted in-between the two consonants to break up the cluster; second, the first consonant could be deleted while the second consonant is retained; and third, the second consonant could be deleted with the retention of the first consonant.

These three processes are observed in the data for this study. The patterns of these three strategies are revealed in Table 1. These patterns revealed that the first strategy $\left(\mathrm{C}_{1} \mathrm{~V}_{0} \mathrm{C}_{2}\right)$ is frequently used.

Examples in Table 2 demonstrate the most frequent process, i.e. vowel epenthesis after $C_{1}$, i.e. $\left\{C_{1} V_{0} C_{2} V\right\}$.

The second process, which deletes $\mathrm{C}_{1}$, and retains $\mathrm{C}_{2}$ (i.e. $\mathrm{C}_{1} \mathrm{C}_{2} \mathrm{~V} \rightarrow\left\langle\mathrm{C}_{1}>\mathrm{C}_{2} \mathrm{~V}\right.$ ) is shown in the example (Table 3).

The third process, $\mathrm{C}_{1} \mathrm{C}_{2} \mathrm{~V} \rightarrow \mathrm{C}_{1}<\mathrm{C}_{2}>\mathrm{V}$, also occurs only in a limited set of clusters. The words in the examples (Table 4) illustrate this pattern.

This study supports the proposal that among the three processes discussed above, the most frequent is vowel epenthesis after $\mathrm{C}_{1}$ in loanword adaptation.

\subsection{Modification of CCC Clusters at the Word-Initial Position}

Some of the foreign words borrowed into Yoruba contain multiple consonants. Foreign words with compound consonants are not common in the borrowed words, probably because of the distinguishing factors between the syllable templates of the two languages. In the data, there are a few compound consonant clusters containing three components.

Whenever a cluster with $\mathrm{C}^{3}$ at the onset is borrowed into Yoruba, it usually undergoes modification through 
Table 1. Loanword adaptation of onset CC clusters.

\begin{tabular}{cccc}
\hline $\mathbf{C}_{1} \mathbf{V}_{\mathbf{0}} \mathbf{C}_{2}$ & $<\mathbf{C}_{1}>\mathbf{C}_{2} \mathbf{V}$ & $\mathbf{C}_{\mathbf{1}}<\mathbf{C}_{2}>\mathbf{V}$ & Total \\
\hline $161(97.58 \%)$ & $2(1.21 \%)$ & $2(1.21 \%)$ & 165 \\
\hline
\end{tabular}

Table 2. Vowel epenthesis after the first consonant.

\begin{tabular}{|c|c|c|}
\hline Foreign Word & Borrowed Form & Gloss \\
\hline /breik/ & [búréèkì] & break \\
\hline /bleid/ & [búleèdi] & blade \\
\hline /fridz/ & [fírî̀̇ì] & fridge \\
\hline /fri:/ & [fírì] & free \\
\hline /græf/ & [gírááfù] & graph \\
\hline /greip/ & [gíréèpù] & grape \\
\hline$/ \mathrm{kl} \Lambda \mathrm{t} \rho /$ & [kíloวfi] & clutch \\
\hline /klæs/ & [kíláasì] & class \\
\hline /plæn/ & [kpúláanì] & plan \\
\hline /plot/ & [kpúlootì] & plot \\
\hline /sks:t/ & [síkéctì] & skirt \\
\hline /ska:f/ & [síkáafù] & scarf \\
\hline
\end{tabular}

Table 3. Deletion of first consonant.

\begin{tabular}{ccc}
\hline Foreign Word & Borrowed Form & Gloss \\
\hline /steIfən/ & {$[$ té $j$ ] } & station (police) \\
/sta:t $/ /$ & {$[$ táà $j \mathrm{i}]$} & starch \\
\hline
\end{tabular}

Table 4. Deletion of second consonant.

\begin{tabular}{ccc}
\hline Foreign Word & Borrowed Form & Gloss \\
\hline /praiməri/ & [pámárì] & primary \\
/stıərıy/ & {$[$ [iárĩ] } & steering \\
\hline
\end{tabular}

vowel epenthesis to break up the sequential consonants to make it conform to the syllable rules of the recipient language. During this process, the second consonant is deleted (i.e. $\mathrm{C}_{1} \mathrm{~V}_{\mathrm{o}}<\mathrm{C}_{2}>\mathrm{C}_{3} \mathrm{~V}$ ). There is also a case of deletion of first consonant and replacement of the third consonant with another different consonant (i.e $\mathrm{C}_{1}<\mathrm{C}_{1}>$ $\left.\mathrm{C}_{2} \mathrm{~V}_{0} \mathrm{C}_{3} \mathrm{~V}\right)$.

These patterns of adaptation are listed in Table 5 .

Examples for the adaptation of CCC onset clusters are demonstrated in Table 6.

\subsection{Nativization of Foreign CC Cluster Coda}

The simplification phonological processes involved in resolving foreign coda CC clusters is in two-fold; a consonant may be deleted completely from the lexical item when it enters the recipient language and secondly, a foreign syllable structure may be resyllabified through an epenthetic vowel to make it conform to the local syllable template.

Table 7 is the summary of the manifestation of various processes of segment preservation and deletion. In most of the cases, the two phonemes are either preserved or one of the phonemes is preserved while the other is deleted. 
Table 5. Loanword adaptation of CCC onset clusters.

\begin{tabular}{cccc}
\hline $\mathbf{C}_{\mathbf{1}} \mathbf{V}_{\mathbf{0}}<\mathbf{C}_{2}>\mathbf{C}_{3} \mathbf{V}$ & $\mathbf{C}_{\mathbf{1}} \mathbf{V}_{\mathbf{0}} \mathbf{C}_{2} \mathbf{V}_{\mathbf{0}} \mathbf{C}_{3} \mathbf{V}$ & $<\mathbf{C}_{1}>\mathbf{C}_{2} \mathbf{V}_{\mathbf{0}} \mathbf{C}_{3} \mathbf{V}$ & Total \\
\hline $2(33.33 \%)$ & $3(50.00 \%)$ & $(16.67 \%)$ & 6 \\
\hline
\end{tabular}

Table 6. Loanword adaptation of CCC onset.

\begin{tabular}{ccc}
\hline Foreign Word & Borrowed Form & Gloss \\
\hline /streit/ & {$[$ síréètì] } & straight \\
/stro:/ & {$[$ síroo] } & straw \\
/skru:/ & {$[$ súkúrù] } & screw \\
/strark/ & {$[$ síráìì] } & strike \\
/sprait/ & {$[$ sípúráìti $]$} & sprite \\
/stri:t/ & {$[$ títì] } & street \\
\hline
\end{tabular}

Table 7. Resyllabification of coda CC clusters.

\begin{tabular}{cccc}
\hline $\mathbf{C}_{\mathbf{1}} \mathbf{V}_{\mathbf{0}} \mathbf{C}_{2}$ & $<\mathbf{C}_{\mathbf{1}}>\mathbf{C}_{2} \mathbf{V}$ & $\mathbf{C}_{\mathbf{1}}<\mathbf{C}_{2}>\mathbf{V}$ & Total \\
\hline $83(69.17 \%)$ & $16(13.33 \%)$ & $23(19.17 \%)$ & 120 \\
\hline
\end{tabular}

The data in Table 8 illustrate the adaptation of coda CC clusters through vowel epenthesis.

The final clusters in the examples (Table 9) are adapted through the deletion of the first consonant while the second consonant is resyllabified by vowel epenthesis.

The third process in the adaptation of foreign CC Coda is through the deletion of the second segment while the first segment is resyllabified by vowel insertion. This is demonstrated in the example (Table 10).

\subsection{Resyllabification of CCC Clusters Word-Finally}

As earlier noted, CCC cluster at the coda is not common in the borrowed words but when it is borrowed, it also undergoes modification through the insertion of a vowel and consonant deletion. Studies in loanword phonology have prescribed four different ways by which foreign words with triple consonants are nativized. They are:

i) deletion of the first and the third phonemes;

ii) deletion of the second phoneme;

iii) deletion of third phoneme and;

iv) deletion of the second and third phonemes.

These four types are also applicable to English words that are borrowed into Yoruba. The patterns of these borrowing are summarized in Table 11.

The data below illustrate some of the processes aimed at resolving $\mathrm{C}_{1} \mathrm{C}_{2} \mathrm{C}_{3}$ coda clusters. The first process is the deletion of the first and the third phonemes.

$\begin{array}{lll}\begin{array}{l}\text { Foreign Words } \\ \text { /æygl/ }\end{array} & \begin{array}{l}\text { Borrowed Form } \\ \text { [áńgù] }\end{array} & \begin{array}{l}\text { Gloss } \\ \text { "angle" } \\ \text { /bæygl] }\end{array} \\ \text { [báńgú] } & \text { "bangle" }\end{array}$

The second process is the deletion of second phoneme. Example of such deletion is given below.

$\begin{array}{lll}\begin{array}{l}\text { Foreign Words } \\ \text { /mi:zlz/ }\end{array} & \begin{array}{l}\text { Borrowed Form } \\ \text { [mísúùsi] }\end{array} & \text { Gloss } \\ & \text { "measles" }\end{array}$

The third process under this strategy involves the deletion of the third phoneme of the member-consonant in coda. The data revealed only two instances that are demonstrated below.

$\begin{array}{lll}\text { Foreign Words } & \text { Borrowed Form } & \text { Gloss } \\ \text { /kændl/ } & \text { [káńdù] } & \text { "candle" } \\ \text { /b } \Lambda \text { ndl/ } & \text { [bəńdù] } & \text { "bundle" }\end{array}$

Deletion of the second and the third phonemes is fourth process to adapt CCC coda clusters. The data attested only one instance of this type of adaptation. 
Table 8. Resyllabification of coda CC through vowel epenthesis.

\begin{tabular}{|c|c|c|}
\hline Foreign Word & Borrowed Form & Gloss \\
\hline /milk/ & [mílîikì] & milk \\
\hline /sılk/ & [sílîikì] & silk \\
\hline$/ \mathrm{sink}$ & [sínkì] & sink \\
\hline /terbl/ & [tábìlì] & table \\
\hline /barbl/ & [bíbélì] & bible \\
\hline /belt/ & [bélíitì] & belt \\
\hline /flæsk/ & [fúlásìkì] & flask \\
\hline /plænt/ & [kpúláǹtì] & plant \\
\hline /lent/ & [léǹtì] & lent/lenght \\
\hline /tælent/ & [táléṅti] & talent \\
\hline
\end{tabular}

Table 9. Deletion of the first consonant.

\begin{tabular}{|c|c|c|}
\hline Foreign Word & Borrowed Form & Gloss \\
\hline /boult/ & [bóòtù] & bolt \\
\hline /fi:ld/ & [fîidì] & field \\
\hline /rISAlt/ & [rìsวotì] & result \\
\hline /soks/ & [sวosì] & socks \\
\hline / felf/ & [ $\left.\int \varepsilon \dot{\varepsilon} \dot{\varepsilon} f u ̀\right]$ & shelf \\
\hline /f̧lt/ & [fortì] & fault \\
\hline /molt/ & [mכotì] & malt \\
\hline /respect/ & [resìpéćtì] & respect \\
\hline /kəntrəkt/ & [końtíráàti] & contract \\
\hline /frlm/ & [fî̀mù] & film \\
\hline
\end{tabular}

Table 10. Deletion of the second segment.

\begin{tabular}{|c|c|c|}
\hline Foreign Word & Borrowed Form & Gloss \\
\hline /æpl/ & [ákpù] & apple \\
\hline /pəust/ & [kpóòsì] & post \\
\hline$/ \Lambda \mathrm{nkl} /$ & [ońkù] & uncle \\
\hline /gerbl/ & [gébù] & gable \\
\hline /nIdl/ & [nídù] & needle \\
\hline /nozl/ & [nosù] & nozzle \\
\hline /hənərəbl/ & [honכrébù] & honourable \\
\hline /paund/ & [рэũ] & pound \\
\hline /ว:gənist/ & [Jgánîsì] & organist \\
\hline /bobl/ & [bobù] & bobble \\
\hline /vənərəbl/ & [fénérébù] & venerable \\
\hline /revrənd/ & [réfúréćc̀nì] & reverend \\
\hline /spektıkl/ & [sípćtíkù] & spectacle \\
\hline
\end{tabular}


Table 11. Nativization of CCC coda clusters.

\begin{tabular}{cccc}
\hline$<\mathbf{C}_{1}>\mathbf{C}_{2} \mathbf{V}_{\mathbf{0}}<>$ & $\mathbf{C}_{\mathbf{1}} \mathbf{V}_{\mathbf{0}}<\mathbf{C}_{2}>\mathbf{C}_{3} \mathbf{V}_{\mathbf{0}}$ & $\mathbf{C}_{\mathbf{1}} \mathbf{V}_{\mathbf{0}} \mathbf{C}_{2} \mathbf{V}_{\mathbf{0}}<\mathbf{C}_{3}>$ & $\mathbf{C}_{\mathbf{1}} \mathbf{V}_{\mathbf{0}}<\mathbf{C}_{2}><\mathbf{C}_{3}>$ \\
\hline $2(33.33 \%)$ & $1(16.67 \%)$ & $2(33.33 \%)$ & $1(16.67 \%)$ \\
\hline
\end{tabular}

$\begin{array}{lll}\begin{array}{l}\text { Foreign Words } \\ \text { /goglz/ }\end{array} & \begin{array}{l}\text { Borrowed Form } \\ \text { [gogù] }\end{array} & \begin{array}{l}\text { Gloss } \\ \text { "goggles" }\end{array}\end{array}$

\subsection{Phonotactic Nativization of CCCC Codas}

A sequence of four consonants word-initially is not permitted in the onset but in the coda of English syllable; therefore, it is not attested in the data. The only instance of $\mathrm{C}_{1} \mathrm{C}_{2} \mathrm{C}_{3} \mathrm{C}_{4}$ cluster in the coda is given in the example below. The constituent phonemes in this cluster are adapted in a way that is similar to consonants in other types of coda structures.

\section{Foreign Words} /pimplz/

\section{Borrowed Form}

[kpíńkpúùìi]

\section{Gloss}

"pimples"

In summary, data analyses reveal that the patterns of simplification strategies (i.e. consonant retention or deletion, vowel insertion and resyllabification) employed to resolve simple consonant clusters word-initially are akin to those involve in resolving multiple consonant clusters.

\section{Phonotactic Adjustments at the Word-Final Positions}

Two processes (consonant deletion and epenthesis) are common in the adaptation of foreign words into a local language. Data analyses in this study confirm that vowel insertion is commonly used.

Examples of vowel insertion and consonant deletion of obstruents coda are given (Table 12). For instance, the final codas in test and post are adapted by vowel insertion and resyllabification. The loan forms for the two words are [téżsi] and [póóśs]].

It has also been revealed that out of the three nasals in English, viz: /m, n, y/, only two are attested in Yoruba (i.e $/ \mathrm{m}, \mathrm{n} /$ ); whenever the third one $(/ \mathrm{h} /)$ is borrowed at the coda; it is deleted and either replaced by /n/ (alveolar nasal to velar nasal), oral vowel (/e/) or nasal vowel $(/ \tilde{i} /)$. These three phonemes are adapted through vowel epenthesis and consonant deletion or replacement as demonstrated in the examples below.

The data reveal that $/ \mathrm{m}, \mathrm{n} /$ are frequently resolved through vowel epenthesis $(\mathrm{e} . \mathrm{g}$. /fIlm/ $\rightarrow$ [fíimù] $)$ while /y/ is deleted and replaced by velar nasal (e.g/dekın/ $\rightarrow$ [dékíní]) or oral vowel (e.g. / IIlıy/ $\rightarrow$ [sílè]) and nasal vowel (e.g. /mi:tıy/ $\rightarrow$ [mítĩ]). The examples of these processes are illustrated (Table 13).

Lateral is an acceptable coda in English but when borrowed into Yoruba, it is usually resolved through i-epenthesis or u-epenthesis. This phoneme has a unique feature in the sense that it is said to be complimentarily distributed. A sound is said to be complimentarily distributed when such a sound has two allophones (i.e. the plain and the syllabic). The plain can occur word-initially (e.g. /leis/ $\rightarrow$ [léèsì] lace, word-medially (e.g. /blokk/ $\rightarrow$ [búloski] block and word-finally (e.g. /farl/ $\rightarrow$ [fáili] file while the syllabic occurs only at the word-final position but it is resolved with resyllabification since Yoruba syllable does not permit coda. (e.g. /botl/ $\rightarrow$ [botù] bottle .

Another feature that may interest us about syllabic lateral coda according to Ojo (2014) is the fact that when it is adapted into Yoruba, a new structure is created immediately after the border element of the original syllable structures of a word. In other words, a lexical item that is disyllabic, in the underlying representation (original rendition) may become trisyllabic when it is borrowed into Yoruba. A good example is the alternative rendition of bottle /botl/ $\rightarrow$ [botù] or [botùrù]. This is called syllable Extension ( $\sigma$ Ext), which is technically referred as REDUPLICATION. This is so-called because of the new syllable structure that is added to the existing structures. This process is different from vowel epenthesis. In vowel epenthesis, a vowel is inserted between consonant clusters or after coda element for the purpose of resyllabification while syllable extension (partial reduplication) is a newly generated syllable in addition to the existing one. Second, the two processes have a common feature in that vowel epenthesis can extend a given syllable structure, as well as, reduplication. Examples of the adaptation of lateral Coda are demonstrated (Table 14).

Another peculiarity about this syllable extension is that the new syllable that is generated through this process is triggered off by alveolar tap /r/ which has the same place feature with the foreign lateral coda. By implication, 
Table 12. Vowel epenthesis and consonant deletion of obstruents coda.

\begin{tabular}{|c|c|c|c|}
\hline Foreign Word & Borrowed Form & Gloss & Processes \\
\hline$/ \mathrm{k} \wedge \rho /$ & [kJobù $]$ & cup & C Rep/V Insertion/Vowel Doubling \\
\hline$/ \mathrm{mæp} /$ & [máàkpù] & map & C Rep/V Insertion/Vowel Doubling \\
\hline /gləub/ & [gilóòbù & globe & V Insertion/Vowel Doubling \\
\hline /test/ & [téčsì̀] & test & V Insertion/C Del/Vowel Doubling \\
\hline /poust/ & [póòsì] & post & C Del/Vowel Doubling \\
\hline /ka: & [káàdì] & card & V Insertion/V Doubling \\
\hline /led/ & [léśdì] & lead & V Insertion/V Doubling \\
\hline /keI/ & [kéèkì] & cake & V Insertion/V Doubling \\
\hline /dæməsk/ & [dámáàsì] & damask & V Insertion/C Del/Vowel Doubling \\
\hline /keg/ & [kéċgì] & keg & V Insertion/V Doubling \\
\hline /ska:f/ & [síkáàfù] & scarf & V Insertion/V Doubling \\
\hline$/ \mathrm{t} f \mathrm{i}: \underline{f} /$ & [jūinfù] & chief & C Rep/V Insertion/V Doubling \\
\hline$/ \mathrm{g} \Lambda_{\Lambda} \underline{\mathrm{v}} /$ & [gíloofù̀/ & glove & C Rep/V Insertion/V Doubling \\
\hline$/ \mathrm{b} æ \underline{\theta} /$ & [báàfù] & bath & C Rep/V Insertion/V Doubling \\
\hline /bærəks/ & [báráakì] & barracks & C Rep/V Insertion/V Doubling \\
\hline /plaiəs & [púlájà] & pliers & C Insertion/V Insertion \\
\hline$/ \mathrm{sarz} /$ & [sáìsì] & size & C Rep/V Insertion \\
\hline /bra $\rfloor /$ & [búroJ』i] & brush & V Insertion/V Doubling \\
\hline /polif/ & [poliî́îi] & polish & V Insertion/V Doubling \\
\hline$/ \mathrm{t} \int_{3}: \mathrm{t} \mathrm{f} /$ & {$\left[\int \mathcal{j} \supset \int \hat{i}\right]$} & church & C Rep/V Insertion \\
\hline /keidz/ & [kéèḑì] & cage & V Insertion/V Doubling \\
\hline /t ferndz/ & [ [éèndzì] & change & C Rep/V Insertion \\
\hline
\end{tabular}

Table 13. Nativization of foreign nasal coda.

\begin{tabular}{|c|c|c|c|}
\hline Foreign Word & Borrowed Form & Gloss & Processes \\
\hline$/ \mathrm{d} æ \underline{\mathrm{m}} /$ & [dáàmù] & damn & V Insertion/V Doubling \\
\hline /kəum/ & [kóòmù] & comb & V Insertion/V Doubling \\
\hline /fIlm/ & [fíìmù] & film & V Insertion/V Doubling \\
\hline $\lg \Lambda \underline{\mathrm{m}} /$ & [gวomù] & gum & V Insertion/V Doubling \\
\hline /fəum/ & [fóòmù] & foam & V Insertion/V Doubling \\
\hline$/ \mathrm{t} 3: \underline{\mathrm{n}} /$ & [tọnù] & turn & V Insertion/V Doubling \\
\hline /k3:tən $/$ & [kכtìnì] & curtain & V Insertion/V Doubling \\
\hline /botən- & [botìnì] & button & V Insertion/Nasalization \\
\hline /dəzə⿻上丨/ & [dosìnì] & dozen & V Insertion/Nasalization \\
\hline$/ \int \mathrm{Il} \ln /$ & [Jílè $]$ & shilling & C Rep/V Insertion /y/ $\rightarrow$ /e/ \\
\hline /mi:tıy/ & [mítĩ $]$ & meeting & C Rep/V Insertion $/ \mathrm{y} / \rightarrow / \tilde{\mathbf{1}} /$ \\
\hline /dekın/ & [dékíní] & decking & C Rep/V Insertion /y/ $\rightarrow / \mathrm{n} /$ \\
\hline /stiərIn/ & [síárĩ] & steering & C Rep/V Insertion /y/ $\rightarrow / \tilde{\mathbf{l}} /$ \\
\hline /wi:vin & [wífĩ] & weaving & C Rep/V Insertion $/ \mathrm{y} / \rightarrow / \tilde{\mathbf{1}} /$ \\
\hline
\end{tabular}


Table 14. Adaptation of lateral coda

\begin{tabular}{|c|c|c|c|}
\hline Foreign Word & Borrowed Form & Gloss & Processes \\
\hline /beIl// & [béèlì] & bail & V Insertion/V Doubling \\
\hline /stail// & [sítáì] & style & C Del/V Insertion \\
\hline /pedəl’/ & [péda] & pedal & C Del/V Insertion \\
\hline /botll/ & [botùrù] & bottle & $\sigma$ Ext \\
\hline /bill/ & [bîilì] & bill & V Insertion/V Doubling \\
\hline /eərıə]/ & [éría] & aerial & C Del \\
\hline /ketl/ & [kétùnù] & kettle & $\sigma$ Ext \\
\hline$/ \mathrm{fr}_{\mathrm{I}} / /$ & [fíilì] & fill & V Insertion/V Doubling \\
\hline /farl/ & [fáilì] & file & V Insertion \\
\hline /baibl// & [bíbélì] & bible & V Insertion \\
\hline /terbl// & [tébùrù] & table & $\sigma$ Ext \\
\hline /əridzinəl]/ & [эrídzína] & original & C Del \\
\hline /fell/ & [féèlì] & fail & V Insertion/V Doubling \\
\hline /pentsəㅣ/ & [pénsùrù] & pencil & $\sigma$ Ext \\
\hline /skul/ & [ [jùkúrù] & school & $\sigma$ Ext \\
\hline
\end{tabular}

in some cases, as observed in the data, alveolar lateral /l/ assimilates the features of alveolar tap / $\mathrm{r} /$ when it is adapted as a coda in Yoruba. This is perhaps so because the two phonemes shared the same place feature (i.e alveolar). Besides, it is also noticeable in the data that where the processed borrowed word resulted into partial reduplication of syllable, /l/ usually assimilates /r/. Examples of such partial reduplication of syllables are seen in "school”, “pencil”, “bottle”, “kettle”, etc. as demonstrated above (see Ojo, 2014).

\section{Conclusions}

Some foreign syllable structures were imported into Yoruba basically for commercial purposes. This language contact all started when the need to fill the communication gap between the whites and the blacks (Yorubas) arose. The reason for this is not far-fetched. Most of the foreign words have no substitutes in the native language and as a result, they were required to embrace these foreign lexical items while speaking in their mother tongue. These foreign words were fully adopted into the linguistic system of Yoruba.

However, the two languages (i.e. English and Yoruba) operate different syllable templates. Therefore, whenever a foreign word is adapted in the local language, it usually undergoes phonotactic adjustments to conform to the syllable canon of the recipient language. These modifications are not unconnected with perceptual similarity as proposed by Steriade (2002) and developed by Miao (2005). The implication of this is that, the adapted word is not too different from the original form irrespective of the adjustment it has undergone. This is the exact pattern of any English word borrowed into Yoruba.

\section{References}

Brasington, R. (1997). Cost and Benefit in Loanword Adaptation. In I. Richard, et al. (eds.), Reading Working Paper in Linguistics (Vol. 3, pp. 1-19). http://www.personal.rdg.ac.uk

Dupoux, E., \& Perperkamp, S. (2002). The Phonetic Hypothesis: How Phonology Impacts Speech Perception and Vice Versa. Paper Presented at the Second International Conference on Contrast in Phonology. University of Toronto.

Kang, Y. (2003). Perceptual Similarity in Loanword Adaptation: English Postvocalic Word-Final Stops in Korean. Phonology, 20, 219-273. http://dx.doi.org/10.1017/S0952675703004524

Kang, Y. (2007). Interlanguage Segmental Mapping as Evidence for the Nature of Lexical Representation. Language and Linguistic Compass, 1, 1-16. 
Kenstowicz, M. (2007). Salience and Similarity in Loanword Adaptation: A Case Study from Fijian. Language Sciences, 29, 316-340. http://dx.doi.org/10.1016/j.langsci.2006.12.023

Miao, R. Q. (2005). Loanword Adaptation in Mandarin Chinese: Perceptual, Phonological and Sociolinguistic Factors. Ph.D Dissertation. Stony Brook University.

Ojo, G. A (2014). A Descriptive Phonological Study of the Phonotactic Constraints in the Code-Mixed Yoruba-English Bilingual Lexicon. Unpublished Ph.D. Dissertation, Ado-Ekiti: Ekiti State University.

Silverman, D. (1992). Multiple Scansions in Loanword Phonology: Evidence from Cantonese. Phonology, 9, 289-328. http://dx.doi.org/10.1017/S0952675700001627

Steriade, D. (2002). The Phonology of Perceptibility Effect: The P-Map and Its Consequences for Constraint Organisation. Unpublished Manuscript UCLA.

Uffmann, C. (2006). Epenthetic Vowel Quality in Loanwords: Empirical and Formal Issues. Lingua, 116, 1079-1111. http://dx.doi.org/10.1016/j.lingua.2005.06.009

Yip, M. (1993). Cantonese Loanword Phonology and Optimality Theory. Journal of Eastern Asian Linguistics, 2, $261-291$. http://dx.doi.org/10.1007/BF01739135 